\title{
Analyzing the Participatory Repertoire of a U.S. Educated EFL Teacher in Saudi Arabia
}

\author{
Yin Lam Lee-Johnson \\ Asst. Prof., Webster University, St Louis, USA, yleejohnson31@webster.edu
}

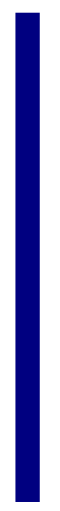

\begin{abstract}
The KSA has become a popular country for Americans to work as an EFL teacher in the recent years because of the payment and cultural experience (Hastings, 2012). Due to the wide social distance between the KSA and USA, the teachers had to adapt to the expectation and become legitimate participants (Lave and Wenger, 1991) in the local communities. This qualitative case study includes turnby-turn discourse analysis of the interview data collected from a U.S.-educated MA TESOL graduate, Amy, (born and raised in the USA) through the lens of Bakhtin's carnivalesque (1984). The study also included the interview with Hidy, who was born and raised in the KSA, as a reference to compare and contrast the data collected from Amy. The findings reveal that the U.S.-educated teacher, Amy, used laughter as a rhetorical tool in the interview to contest the cultural expectation of her gender role in the KSA. The findings suggest that cultural rules and taboos are constructed in situ through individual experience.
\end{abstract}

Key Words: Bakhtin, carnivalesque, rhetorical, gender rights, feminism, teacher education, expatriate

\section{INTRODUCTION}

"One of the main purposes of using English in the Arab world is to call for Islam and unveil its true message to English speaking countries and people." (Mahmund, 2015, p. 71) "English performs the instrumental function as a medium of learning at various stages in the educational system of Saudi Arabia." (Al-Seghayer, 2005, p. 125) Because of this importance, more and more U.S.-educated EFL teachers teach in the Kingdom of Saudi Arabia (KSA) for both the income and cultural experiences (Hastings, 2012). However, the social distance (Schumann, 1976) between the KSA and the USA is considerable (Glowacki-Dudka, Usman, \& Treff, 2008). The cultural adaptation required for these expatriate EFL teachers is challenging, especially when women's rights are in question. Therefore, it is important to understand more about these EFL teachers' participatory repertoire in the KSA.

Bakhtin's carnivalesque (1984) is a literary frame which foregrounds the subversive power for contesting the authority. According to Bakhtin (1984), "Laughter liberates not only from external censorship but first of all from the great interior censor; it literates from the fear that developed in man." (p. 94) As such, laughter is emancipation and a 
powerful tool of subversion. Many scholars studied the various forms and functions of laughter (Glenn, 1995; Glen \& Holt, 2013; Joris, 2014) using conversational and discourse analyses. However, seldom do they investigate the power of laughter. Therefore, Bakhtin's carnivalesque is borrowed from literary studies to analyze how Amy contested the cultural expectation of her in the KSA. The research questions are: (1) What are the taboos for teaching EFL and living in the KSA? (2) What is the participatory repertoire of Amy in the KSA? (3) Why do educational institutions in the KSA hire U.S.-educated EFL teachers?

\section{Review of Literature}

Academic studies offer minimal information about how expatriate EFL teachers contest their female rights in the KSA. A search of JSTOR, EBSCO, ERIC, and Google Scholar, reveals no academic studies which investigated how expatriate EFL teachers contest their rights while teaching in the KSA. Therefore, this study is intended to fill this research gap in the literature.

The majority of related studies about EFL teaching in the KSA used questionnaires to gather data, and their overarching claim was that the current teaching practice in the KSA needs to be changed to reflect the local culture (Al-Asmari, 2005; Liton, 2012, 2013; Moskovsky \& Alrabai, 2009; McMullen, 2009). These studies focused on how expatriate teachers teach in international schools (Naidoo, 2007) and EFL teachers' work experience in the KSA (Alshuaifan, 2010; Etri, 2015; Glowacki-Dudka, Usman, \& Treff, 2008; Hastings, 2012; Liton, 2013; Mekheimer \& Aldosari, 2011).

Through questionnaires among teachers at an international school in the KSA, Naidoo (2007) found that "when teachers enter the world of international/multicultural teaching, they enter a situation that is different for [sic] which they have been trained" (p. 6). The majority of the teachers did not understand multicultural education and the cultural need of the students, who share different linguistic and cultural backgrounds. Liton's (2013) study of 25 EFL teachers work experience at renowned Saudi universities further suggested a disconnection between local cultural practices and EFL education in the classroom while Mekheimer \& Aldosari (2011) found that cultural practice needed to be reinforced in the EFL curriculum based on their study of 25 faculty and 33 students' experience in a Saudi university. Alshuaifan's (2010) survey of EFL practitioners and faculty showed the impact of the classroom which was more communicative rather than grammar-based. Finally, in interviews with 11 EFL teachers, Hastings (2012) also found a low level of job satisfaction and poor work relationships between the teachers and students.

One aspect of great significance was gender issues. Etri (2015) studied expatriate teachers from the US, UK, Pakistan, Philippines, Jordan, Morocco, Malaysia, and Sudan, and claimed that "Saudi gender segregation laws are fully implemented by the university" (p. 172) and thus it was important for these expatriate teachers to have cultural sensitivity before teaching in the KSA. Through the lens of a conflict, Glowacki-Dudka, Usman, \& Treff (2008) wrote about the power relationship between an American female faculty and a Saudi female faculty at a university in the KSA analyzing multiple layers of complexities about gender role and cultural adaptation 
when the two informants worked together. In their article, the American faculty took an individualistic approach and discussed some of her personal observations about the curriculum and teaching practices with the Dean. However, her Saudi colleague, who assumed a more collective approach, felt that trust was betrayed because in the Saudi culture, the American colleague was expected to involve her in any conversation with the administration.

Based on the literature review and in particular, Hastings' (2012) findings, it is evident that the overarching concern is how expatriate EFL teachers position themselves in their immediate communities. It is therefore important for us to understand their participatory repertoire, i.e., their range of participation as new comers in the KSA.

\section{Theoretical Framework}

Bakhtin (1984) referred to carnival festivities filled with giants, dwarfs, monsters, trained animals, clowns, and fools in the medieval era. In Bakhtin's world, the clown had social meaning, which is to laugh and mock repression. As such, the feast of fools had the subversive power to create new forms of speech, which expose the existing official world. Taylor (1995), echoes this view, "carnivalesque laughter had the potential to demystify reality insofar as it provided the means for probing the objects around it." (p. 28). Pomorska (1984) claimed that Bakhtin used the carnival to reveal "the unvarnished truth under the veil of false claims and arbitrary ranks" in official culture (p. x). Laughter is thus a powerful subversive tool to contest the authority or the culturally accepted norm. According to Bakhtin (1984), there is a double aspect of the world and of human life, because "the men of the Middle Ages participated in two lives: the official and the carnival life" (p. 96). In this study, Amy participated in two lives: the life as a foreign female in KSA and the life as a U.S.-educated intellect. Based on the interview data, there are conflicts between the two lives: the former being defined by the local law and cultural expectations, and the latter being her American life. She used laughter to contest her participatory repertoire in KSA.

The "participatory repertoire" in this study stems from Lave and Wenger's (1991) legitimate periphery participation and Kachru's (1982) bilingual linguistic repertoire. Lave \& Wenger (1991) studied how apprenticeship led to learning and the process was to move from the periphery (new comer) to the center of the practice (master). The key concept that I borrow from their model is "participation." The participant in this study, Amy, was a novice EFL teacher in Saudi Arabia who negotiated for her identity through participating in the local communities. Kachru's (1982) bilingual linguistic repertoire discusses how "the total range of codes which members of a speech community have available for their linguistic interaction" (p. 25). The concept of repertoire is considered effective in describing the range of participation that Amy engaged in as a novice EFL teacher in the KSA.

\section{METHOD}

The research method of this study is based on qualitative case studies (Yin, 2009). The data sources collected have been triangulated (Lincoln \& Guba, 1985) to ensure the credibility and trustworthiness of the study. 


\section{Participants}

The participants have been given pseudonyms to protect their identities. Both participants had completed a TESOL MA in the USA. Amy was born and raised in the United States while Hidy was born and raised in the KSA. Each was invited to a oneon-one semi-structure interview with the researcher in 2014. Amy was an EFL teacher in a private English institute for a year in the KSA. Her all female students ranged in age from 4 to 80 years old and met in classes of approximately 20 students in 6 different proficiency levels. During the first half of the interview, Amy chuckled 38 times and took 42 turns. The researcher postulates that Amy uses laughter as a subversive or emancipation power to contest the local expectation of her as a female. Hidy's interview data was used as a reference to confirm or contest Amy's account of her teaching experience in the KSA.

\section{Data Sources}

The interviews with Amy and Hidy were audiotaped and transcribed by the researcher. The two participants were also asked to bring some relevant cultural artifacts related to their teaching and learning experiences in the KSA. Both brought textbooks that were used in the KSA which were collected as secondary data sources to support the findings. Because the aim of the study is to investigate an expatriate EFL teacher's participatory repertoire in the KSA, Amy's interview data was analyzed and used as the major data source in this study. Hidy's interview data was used as a supplementary source for comparing and contrasting Amy's account. The interview questions are appended at the end of this article.

\section{Data Analysis}

The major part of data analysis stems from the discourse analysis (Bloome, et al., 2005) of the interview data from Amy and Hidy using turn-by-turn analysis.

\section{FINDINGS \& DISCUSSION}

In the following section, the findings will be discussed in response to the research questions. Based on the research questions, the researcher reviewed the transcriptions, searched for the responses that are related to the research questions, and compiled the following tables.

\section{What are the taboos for teaching EFL and living in the KSA?}

Table 1: Taboos identified by the participants

\begin{tabular}{|c|c|c|}
\hline & Interview with Amy & Interview with Hidy \\
\hline $\begin{array}{l}\text { Women need to be } \\
\text { accompanied by blood related } \\
\text { men in public. }\end{array}$ & $\begin{array}{l}\text { So women are not allowed to go } \\
\text { anywhere in public alone. }\end{array}$ & (no comment) \\
\hline $\begin{array}{l}\text { Females cannot visit a male } \\
\text { doctor alone. }\end{array}$ & $\begin{array}{l}\text { I am pretty sure that Saudi female } \\
\text { cannot go alone to a Saudi male doctor. }\end{array}$ & \\
\hline
\end{tabular}


Table 1: Taboos identified by the participants (continued)

\begin{tabular}{|c|c|c|}
\hline & Interview with Amy & Interview with Hidy \\
\hline $\begin{array}{l}\text { Women } \\
\text { should not let } \\
\text { down their } \\
\text { hair. }\end{array}$ & $\begin{array}{l}\text { They see it as actually disrespectful if a woman } \\
\text { lets down her hair, and they are offended by that. }\end{array}$ & $\begin{array}{l}\text { Researcher: I can show my hair in class? } \\
\text { Hidy: Yeah, because you'll be teaching } \\
\text { women. } \\
\text { Researcher: So, between women you can see } \\
\text { the hair. Interesting. } \\
\text { Hidy: I know a lot of people think that you } \\
\text { have to cover all time. But, no. }\end{array}$ \\
\hline $\begin{array}{l}\text { Women work } \\
\text { at McDonalds } \\
\text { cannot show } \\
\text { their faces or } \\
\text { hands. }\end{array}$ & $\begin{array}{l}\text { When we order food, like McDonalds, the women } \\
\text { would open the doors and just stick the arms out } \\
\text { so the men could see them with the money and the } \\
\text { men would take the money. }\end{array}$ & (no comment) \\
\hline $\begin{array}{l}\text { Women can } \\
\text { only choose } \\
\text { from five } \\
\text { majors in } \\
\text { college. }\end{array}$ & $\begin{array}{l}\text { Because another thing about college is that there } \\
\text { are only } 5 \text { majors that Saudi females can major in. } \\
\text { Medicine is not one of them. Business is a big } \\
\text { one. Um- I don't know what to call it. } \\
\text { Administrative like to be a secretary. Like that } \\
\text { was a major. Pharmacy. That's a huge one. } \\
\text { Pharmacy. They love it, and they do it a lot. } \\
\text { English teachers. }\end{array}$ & $\begin{array}{l}\text { They can legally take jobs but not culturally } \\
\text { acceptable. Bankers, companies that only } \\
\text { have women... Business, education, } \\
\text { pharmacy, dentistry, and humanities. No one } \\
\text { would accept having female doctors. }\end{array}$ \\
\hline $\begin{array}{l}\text { A man shall } \\
\text { not see } \\
\text { another } \\
\text { woman except } \\
\text { the wife, } \\
\text { mother, or } \\
\text { sister. }\end{array}$ & $\begin{array}{l}\text { In their religion a man is not supposed to see } \\
\text { another woman except the wife, mother, or sister. }\end{array}$ & $\begin{array}{l}\text { They are not just talking about physical } \\
\text { contact. They are talking about having a } \\
\text { relationship with man. But it's like the rule } \\
\text { to cover face it's fading, and no one actually } \\
\text { follows that rule. But it's not fully accepted } \\
\text { culturally, but it's starting to become more } \\
\text { and more acceptable. }\end{array}$ \\
\hline $\begin{array}{l}\text { Men cannot go } \\
\text { into a girls' } \\
\text { school. }\end{array}$ & $\begin{array}{l}\text { We actually have security guards at the entrance } \\
\text { at all times to prevent any man from going in. }\end{array}$ & (no comment) \\
\hline
\end{tabular}

Table 1: Taboos identified by the participants (continued)

\begin{tabular}{|c|c|c|}
\hline Dating & $\begin{array}{l}\text { Yeah dating is a big taboo. The } \\
\text { religious police's main role is to prevent } \\
\text { man and woman to be together beyond } \\
\text { marriage in public. }\end{array}$ & So, dating would not be suitable. \\
\hline $\begin{array}{l}\text { Celebrate } \\
\text { birthdays }\end{array}$ & $\begin{array}{l}\text { Oh, another really weird one that you'll } \\
\text { never guess is it is like kind of against } \\
\text { their religion to talk about your birthday } \\
\text { or to celebrate your birthday because } \\
\text { you are only allowed. You are only } \\
\text { allowed to celebrate the date for God. }\end{array}$ & $\begin{array}{l}\text { But again there are certain people who do not believe } \\
\text { in birthdays. Because the restrictive religious people } \\
\text { they only celebrate the two holidays we have in Islam, } \\
\text { Eid Al-Fitr and Eid Al-Adha They only believe in } \\
\text { these two. So birthdays, flag days, or memorial day. } \\
\text { They don't believe in these things. }\end{array}$ \\
\hline $\begin{array}{l}\text { Politics } \\
\text { and } \\
\text { religion }\end{array}$ & $\begin{array}{l}\text { Politics. Religion. But another thing is } \\
\text { talking about religion other than Islam } \\
\text { because of the theocracy. }\end{array}$ & $\begin{array}{l}\text { Talking negatively about the government won't be } \\
\text { acceptable. It's not like wrong or something; it's } \\
\text { people there won't accept. They are loyal to the } \\
\text { country, so they will feel offended if someone talk } \\
\text { negatively about the country. }\end{array}$ \\
\hline Music & (no comment) & $\begin{array}{l}\text { Music. I know in the ESL music we learned a lot of } \\
\text { activities, and I remember having the One } \\
\text { Direction song, and it was all great, but I was not } \\
\text { sure if I can do that in Saudi Arabia because you } \\
\text { cannot play music in class. }\end{array}$ \\
\hline Pork & (no comment) & Also, pork is not allowed in Saudi Arabia. \\
\hline
\end{tabular}

International Journal of Instruction, July $2016 \bullet$ Vol.9, No.2 
Amy responded to the question about taboos by making a distinction between women taboos and general taboos. For a U.S.-educated EFL teacher like Amy, the women and general taboos are important to be recognized, because they are not supposed to use these as examples in the classroom. Also, they need to conform to these sociocultural rules while living in the KSA.

\section{What is the participatory repertoire of Amy in the KSA?}

Amy's participatory repertoire as a newcomer EFL teacher in the KSA can be grouped as teaching and social related categories. Her participatory repertoire reflects and refracts (Voloshinov, 1986) the social distance between the USA and the KSA. Also, it reveals how Amy's female identity had been contested and negotiated in the KSA.

Table 2: Amy's participatory repertoire

\begin{tabular}{|c|c|c|c|}
\hline $\begin{array}{l}\text { Turn } \\
\text { No. }\end{array}$ & Interview with Amy & $\begin{array}{l}\text { Inside or } \\
\text { Outside of } \\
\text { School }\end{array}$ & Researcher Interpretation \\
\hline 2 & $\begin{array}{l}\text { I was only allowed to teach conversation. Because } \\
\text { they think that native speakers are the only ones } \\
\text { who can adequately teach them how to speak. } \\
\text { (chuckle) } \\
\text { I was the only native speaker (chuckle) in the } \\
\text { entire building. }\end{array}$ & In school & $\begin{array}{l}\text { Native speakers like } \text { Amy are } \\
\text { highly valued in school, } \\
\text { particularly for } \\
\text { speaking. }\end{array}$ \\
\hline 8 & $\begin{array}{l}\text { And now that I left I am pretty sure they have } \\
\text { Syrian teachers teach the conversation. They just } \\
\text { can't get Americans. There were no Americans } \\
\text { there. (chuckle) }\end{array}$ & In school & $\begin{array}{l}\text { American teachers are valued } \\
\text { over Syrian teachers. }\end{array}$ \\
\hline 12 & $\begin{array}{l}\text { Not really. Not females. Because the owner of the } \\
\text { compound that I was on lived in Missouri and } \\
\text { lived abroad for } 20 \text { years. His kids went to the K- } \\
12 \text { school in Missouri. So he was like you're from } \\
\text { Missouri? Saudis are all about connections. So I } \\
\text { was able to get a place in there. (chuckle) }\end{array}$ & $\begin{array}{l}\text { Outside of } \\
\text { School }\end{array}$ & $\begin{array}{l}\text { It is impossible for a female to } \\
\text { rent a place in Saudi without } \\
\text { connections. }\end{array}$ \\
\hline 14 & $\begin{array}{l}\text { So, women are not allowed to go anywhere in } \\
\text { public alone. I guess not. Now I did. (chuckle) }\end{array}$ & $\begin{array}{l}\text { Outside of } \\
\text { School }\end{array}$ & $\begin{array}{l}\text { Females cannot show up in } \\
\text { public alone. }\end{array}$ \\
\hline 14 & $\begin{array}{l}\text { So, I have to wear head to toe covering, only my } \\
\text { eyeballs showed (chuckle). }\end{array}$ & $\begin{array}{l}\text { Outside of } \\
\text { School }\end{array}$ & $\begin{array}{l}\text { Females have to cover up from } \\
\text { head to toe, showing only } \\
\text { eyeballs. }\end{array}$ \\
\hline 16 & $\begin{array}{l}\text { Father, husband, or brother. Even if the funny part } \\
\text { to me was that - even if it's like a two year old like } \\
\text { nephew that still counts. You are good to go. You } \\
\text { have to go with a male. Even if a baby. (chuckle) }\end{array}$ & $\begin{array}{l}\text { Outside of } \\
\text { School }\end{array}$ & $\begin{array}{l}\text { Amy used laughter to mock the } \\
\text { sociocultural rule that female has } \\
\text { to be accompanied by male. }\end{array}$ \\
\hline 20 & $\begin{array}{l}\text { Because I am American. The US Embassy was a } \\
\text { big thing there. Because they don't want to mess } \\
\text { with us. But I tried to pull the American card, } \\
\text { and it didn't work. They were like I don't care } \\
\text { you're American. Cover your hair. (chuckle). }\end{array}$ & $\begin{array}{l}\text { Outside of } \\
\text { School }\end{array}$ & $\begin{array}{l}\text { Amy used laughter as a } \\
\text { subversive tool to contest the } \\
\text { local rule about covering her } \\
\text { hair. }\end{array}$ \\
\hline 28 & $\begin{array}{l}\text { They can't date. No. You cannot date. It's purely } \\
\text { arranged marriage. (chuckle) }\end{array}$ & $\begin{array}{l}\text { Outside of } \\
\text { School }\end{array}$ & $\begin{array}{l}\text { Amy chuckle after talking about } \\
\text { arranged marriage, which shows } \\
\text { her disapproval of the local } \\
\text { practice of arranged marriage. } \\
\end{array}$ \\
\hline
\end{tabular}


32 She said we don't really celebrate birthdays here. Outside of Amy said happy birthday to her So, that's a really weird one. So, I could go on and School coworker, and she got stared at. on but those are just some initial ones. Big taboos. (chuckle) She then found that celebrating birthdays was a taboo.

37 For me that brings up a list of thousands of In School Amy used laughter to contest the possibilities coz here we can major in anything. local rule about women not People major in like gym. You know. (chuckle) being able to freely choose their But no not there. major in college.

51 So, if I had like a contract issue, I will have to go In School Amy chuckle after saying "It's to him because my female managers don't have run by the men", which shows that kind of power. Yes, they run the female that she deliberately highlighted section, but they were not given power, real power the practice that the school was from the company. It's run by the men. (chuckle) run by men.

55 When we order food, like McDonalds, the woman Outside of Amy described how the female would open the doors and just stick the arms, so School workers at McDonalds covered the men could see them with the money and the men would take the money. They give them the change and the bag. And the door just shows the hands. Some of them wear gloves. (chuckle) So yeah. (chuckle)

66 They hire us for accent and they hire us because In School Amy stressed the social status of they think native speakers know everything. Even native speaker being very high in though that's not necessarily true. (chuckle) the KSA.

68 The assumption is that because I am a native In School Amy used laughter to contest the speaker, I will know everything even though I am pretty weak in grammar let's be honest. (chuckle) local assumption about native speakers knowing everything. She did not agree with that assumption personally.

$70 \quad$ I remember he said we have an American teacher In School Amy used this example to show and all the students were like, wow. So, it's almost like a luxury. It's hard to get Americans over there. They were not interested in Canadians. It's all about American teachers. I don't know what that's all about. But, the weird thing is they need British English, so that really doesn't make sense. (chuckle)

82 Especially if those students major in English In School Amy thought that English literature. That's really funny $\mathrm{coz}$ their proficiency level is super low, but they had a degree in English literature. Coz it's taught in Arabic not English. The level, the backgrounds, were basically everything you think of. (chuckle) how Americans were like luxury in the KSA. She stressed that Canadians were not treated the same way as Americans. Amy believed that hiring Americans to teach British English was not logical and rational. literature majors should have a good proficiency level in English. She used laughter and the word, funny, to mock the local practice of using Arabic to teach English literature in college.

84 They are not a rich country they thought that's In School Amy used laughter to stress that expensive. I thought that was a bargain because I was there. (chuckle) It's hard to get an American being an American EFL teacher in the KSA was highly acclaimed. However, she said that tuition was cheap and so it was a bargain. 
In the following analysis, Strauss and Corbin's (1990) selective coding was used. Also, each theme or claim is to be supported or warranted by at least three turns. The themes that emerged from Amy's responses are: a) American teachers are highly valued in school, b) Women's rights are limited in school when compared to the USA, and c) Women's rights are limited outside of school when compared to the USA.

\section{a) American teachers are highly valued in school}

Amy used words like "luxury" (Turn no. 70) and "they just can't get Americans" (Turn no. 8) to describe how she was highly valued by the school. Amy's responses in Turn no. 2, 8, 66, 68, 70, and 84 all corroborate this claim. Though enjoying a highly acclaimed role in school, Amy contested the local assumption that native speakers from the USA know everything. In particular, the local norm in EFL is British English, and it's ironic for the Saudis to assume U.S. teachers have the declarative and procedural knowledge about it (Pasternak \& Bailey, 2004), i.e., know British English as well as how to teach it. Turn no. 66, 68, and 70 corroborate this claim. In Turn no. 70, she said, "It's all about American teachers. I don't know what that's all about. But the weird thing is that they need British English so that really doesn't make sense." (Interview with Amy on May 21, 2014) Amy used laughter as a tool to contest the local practice of trusting U.S. teachers in teaching British English. She said that her British English was very limited. Amy's responses revealed a hierarchy between British, American, Canadian, and Syrian teachers. From Turn no. 8, 70, and 84, it is evident that there is an order of preference as far as the origins of EFL teachers are concerned, and the order is British, American, Canadian, and Syrian. Such hierarchy created an advantage for British and American EFL teachers for finding employment in the KSA.

\section{b) Women rights are limited in school when compared to the USA}

Turn no. 37 reveals how strongly Amy felt about women not having many choices in college. Amy said that American women have thousands of possibilities but the Saudi women only have five possible majors: business, administration, pharmacy, and education (Turn no. 36). Hidy confirmed that there was no law which prevented women from taking certain majors; however, it was not socially acceptable for women to take majors such as medicine and law. A woman can take medicine or law, but she will not be able to find a job and work in the career due to social scrutiny (Interview with Hidy in 2014). Turn no. 51 also corroborates this theme because Amy said that the school was run by men, and she used laughter to mock the fact that women have no real power in school. As a female teacher, Amy "got yelled at from the manager" (Turn no. 70) because she didn't cover her hair. Amy said that "they wanted me to assimilate like that - You would think they would know we don't do it in America. And it's hard for me to just come there and know how they live" (Turn no. 70). By not covering her hair in the administration building in school, Amy contested her female rights in the KSA. She knew that the school administration wanted her to assimilate and conform to the local rules, yet she still tried not to cover her hair because it was difficult for her to adapt to the local rules. 
c) Women's rights are limited outside of school when compared to the USA.

Turn no. 12, 14, 16, 20, 24, 28, 32, and 55 reveal how women's rights are different when compared to the USA. Amy used laughter to mock how she got an apartment without men's help in Saudi Arabia in Turn no. 12. She also used Turn no. 16 to mock and contest the social rule that women have to be accompanied by a male, even it's a baby. Amy mentioned "hair" in Turn no. 20 and 24. She had a lot of trouble due to not covering her hair in the KSA. And every time she used her American citizen identity to go against the local rule about hair covering. She thought that the US Embassy was powerful there, so she could pull the American card, but it didn't work. From these turns, it is evident that Amy felt the difference in women rights in the USA and the KSA.

Through the lens of Bakhtin, it is evident that Amy used laughter to negotiate for her women rights in the KSA. "Laughter has the remarkable power of making an object come up close, of drawing it into a zone of crude contact where one can finger it familiarly on all sides." (Bakhtin, 1981, p. 23) Bakhtin mentioned that laughter is a powerful subversive tool to challenge the authority. Bakhtin (1981) also underscores that laughter is an emancipatory tool. "Laughter demolishes fear and piety before an object, before a world, making of it an object of familiar contact and thus clearing the ground for an absolutely free investigation of it" (p. 23). Amy contested her gender rights by using laughter as an emancipatory tool in the interview.

\section{Why do educational institutions in the KSA hire U.S.-educated EFL teachers?}

In Turn no. 64, Amy (interview, May 21, 2014) said, “I think that even they don't openly say it. They know that the education in America is really good. I think they know that. Because the education system in Saudi is lacking they ban most subjects. Critical thinking is not even on the table for teachers to teach." Amy continued to say that having American teachers was a luxury (Turn no. 70. Also, she said "They hire us for accent, and they hire us because they think native speakers know everything" (Turn no. 66). Based on Amy's response, the educational institutions hire U.S.-educated EFL teachers because it was a prestigious thing to have American teachers, who are from the inner circles (Kachru, 1992). Hidy (Interview, May 29, 2014) said, "It will be different if you learn from a native speaker." As such, even if the educational institutions know that the American EFL teachers might teach very differently than Saudi teachers, they still wanted to hire them because they speak the native language, and the education system is supposed to be very good. Amy and Hidy had very different ideas about why the KSA hired U.S.-educated EFL teachers. But they both agree that American teachers are hired because of the prestige and nativeness in English speaking.

\section{CONCLUSION}

By investigating the participatory repertoire of Amy, who was a U.S.-educated EFL teacher in the KSA for a year, this study purports that laughter is a useful lens to study how the participant contests her female identity inside and outside of the school. During the interview, Amy chuckles 38 turns out of 42 turns. She chuckles whenever there was a cultural conflict between her American and Saudi selves. She used laughter in the 
interview just like a writer uses rhetorical device in writing. Each chuckle has a meaning and function. Based on the analysis of her chuckles and her participatory repertoire inside and outside of school, the findings reflect the hidden assumption of Americanism in EFL education and the imperialistic status of English (British and American) in the KSA.

\section{Acknowledgement}

The author has presented this article at the National Council of Teachers of English Assembly for Research Conference at Eastern Michigan University, USA, on February 7, 2016

\section{REFERENCES}

Alshuaifan, A.S.R. (2010). Key elements of the ESL/EFL teacher preparation program at the University of Ha'il, Saudi Arabia: EFL practitioners and faculty perceptions. Retrieved from Dissertations \&Theses A\&I (3377474).

Al-Asmari, A. M. (2005). The use of internet among EFL teachers at the colleges of technology in Saudi Arabia. Retrieved from Dissertations \&Theses A\&I (3177167).

Al-Seghayer, K. (2005). Teaching English in the Kingdom of Saudi Arabia: Slowly but steadily changing. In G. Braine, (ed.) Teaching English to the World (pp. 125-134). London, UK: Lawrence Erlbaum.

Bakhtin, M. (1981). The Dialogic Imagination. M. Holquist (Ed.). (C. Emerson \& M. Holsquist, Trans.) Austin: University of Texas Press.

Bakhtin, M. (1984). Rabelais and His World. (H. Iswolsky, Trans.) Bloomington: Indiana University Press.

Bloome, D., Carter, S., Christian, B. M., Otto, S., \& Shuart-Faris, N. (2005). Discourse analysis and the study of language and literacy events: A microethnographic perspective. Mahwah, NJ: LEA.

Etri, W. (2015). The road to understanding intercultural sensitivity in English language teaching (ELT) pre-existing for intercultural sensitivity. Arab World English Journal, 6(1), 169-184.

Glenn, P. J. (1995). Laughing at and laughing with: negotiating participant alignments through conversational laughter. In P. ten Have and G. Psathas (eds.), Situated order: studies in the social organization of talk and embodied activities (pp. 43-56). Lanham, MD: University Press of America.

Glen, G., \& Holt, E. (2013). Studies of laughter in interaction. New York: Bloomsbury Academic.

Glowacki-Dudka, M., Usman, I., \& Treff, M. (2008). Intercultural conflicts between close friends: A case study of power relations in continuing education in Saudi Arabia. Convergence, 41(2-3), 41-58. 
Hastings, C.J. (2012). Attitudes and acculturation: A qualitative case study of EFL teachers in Saudi Arabia. Retrieved from Dissertations \&Theses A\&I (3520367).

Joris, V. (2014). Laughter as immanent life-affirmation: Reconsidering the educational value of laughter through a Bakhtinian lens. Educational Philosophy and Theory, 46(2), 148-161.

Kachru, B. (1982). The bilingual linguistic repertoire. In Hartford, B., Valdman, A, \& Foster, C. (eds.) Issues in International Bilingual Education, (pp. 25-52). New York: Plenum Press.

Kachru, B. B. (Ed.). (1992). The other tongue: English across cultures. Urbana and Chicago: University of Illinois Press.

Lave, J., \& Wenger, E. (1991). Situated learning: Legitimate peripheral participation. New York: Cambridge University Press.

Lincoln, Y. S., \& Guba, E. G. (1985). Naturalistic inquiry. Beverly Hills, CA: Sage Publications, Inc.

Liton, H. A. (2012). Developing EFL teaching and learning practices in Saudi colleges: A review. International Journal of Instruction, 5(2), 129-152.

Liton, H. A. (2013). EFL teachers' perceptions, Evaluations and Expectations about English Language Courses as EFL in Saudi Universities. International Journal of Instruction, 6 (2), 19-34.

Mahmund, M. (2015). Culture and English language teaching in the Arab world. Adult Learning, 26(2), 66-72.

McMullen, M. (2009). Using language learning strategies to improve the writing skills of Saudi EFL students: Will it really work? System, 37, 418-433.

Mekheimer, M.A.A. \& Aldosari, H.S. (2011). Impediments to cultural teaching in EFL programmes at a Saudi University. Journal of Intercultural Communication, 26, 2.

Moskovsky, C. \& Alrabai, F. (2009). Intrinsic motivation in Saudi Learners of English as a foreign language. The Open Applied Linguistics Journal, 2, 1-10.

Naidoo, V. (2007). Teacher competence in multicultural schools in Saudi Arbaia. Master thesis. University of South Africa. Retrieved on January 7, 2016, from http://uir.unisa.ac.za/bitstream/handle/10500/2538/dissertation.pdf

Pasternak, M. \& Bailey, K. M. (2004). Preparing non-native and native Englishspeaking teachers: Issues of professionalism and proficiency. In L.D. Kamhi-Stein (Ed.). Learning and teaching from experience: Perspectives on non-native Englishspeaking professionals (pp. 155-175). Ann Arbor: University of Michigan Press.

Pomorska, K. (1984). Forweword. In M. Bakhtin. Rabelais and His World (p. vii-xii). Bloomington: Indiana University Press.

Schumann, J. H. (1976). Social distance as a factor in second language acquisition. 
Language Learning, 26(1), 135-143.

Strauss, A. \& Corbin, J. (1990). Basics of Qualitative Research: Grounded Theory Procedures and Techniques. Newbury Park, CA: Sage Publications. (selective coding, p. 116)

Taylor, B. (1995). Bakhtin, carnival, and comic theory. Retrieved from Dissertations \&Theses A\&I (301493072).

Voloshinov, V. N. (1986). Marxism and the philosophy of language. Cambridge, MA: Harvard University Press.

Yin, R.K. (2009). Case study research: Design and methods. Thousand Oaks, CA: Sage Publications.

\section{Appendix: Semi-structured Interview Questions}

1. Would you tell me about your educational experience as an English instructor or learner in Saudi Arabia?

2. Would you describe the cultural ideologies (such as gender roles, religious practices, and educational philosophy) that exist in the field of education in Saudi Arabia?

3. Would you describe the differences of cultural ideologies that you experienced as a TESL candidate in the USA?

4. Would you describe any taboos in the EFL classroom in Saudi Arabia?

5. Why do educational institutions hire American educated instructors to teach English? What are their goals?

6. Are college level Saudi students more familiar with British, American, or Australian English?

7. Would you tell me about the textbooks and instructional materials (including text and digital) used in college level EFL in Saudi Arabia?

8. Would you tell me the modifications needed for teaching EFL in Saudi Arabia?

9. Any comments that you may want to add? 


\section{Turkish Abstract}

Suudi Arabistan'daki ABD Eğitimli İngilizce Öğretmenlerinin Katılımcı Repertuarlarının Analizi

Suudi Arabistan son yıllarda ödemelerden ve kültürel deneyim dolayısıyla Amerikalılar için İngilizce öğretmeni olarak çalışmak için popüler bir üke olmuştur (Hastings, 2012). SA ve ABD arasındaki geniş sosyal uzaklıktan dolayı öğretmenler beklentilere ayak uydurmak zorundalar ve yerel topluluklarda yasal katılımcilar olmak zorundadırlar (Lave and Wenger, 1991). Bu nitel çalışma Amy (ABD doğumlu ve yetişmiş) ile yapılan görüşmenin Bakhtin'in karnavaleks (1984)'i gözüyle yapılan bir diskors analizidir. Çalışma ayrıca SA doğan ve büyüyen Hidy ile yapılan görüşmeyi de Amy'den toplanan verilerle karşılaştırmak için bir referans olarak içermektedir. Bulgular ABD eğitimli Amy'nin görüşmede gülmeyi SA'daki cinsiyet rolünün kültürel beklentileriyle yarışmak için bir retorik araç olarak kullandığını göstermiştir. Bulgular ayrıca kültürel kural ve tabuların bireysel deneyim yoluyla oluşturulduklarını göstermiştir.

Anahtar Kelimeler: Bakhtin, karnavaleks, retorik, cinsiyet hakları, feminism, öğretmen eğitimi, yabancı ülkede yaşayan

\section{French Abstract}

Analyser le Répertoire Participatif d'un Professeur d'EFL Instruit américain dans l'Arabie Saoudite

Le KSA est devenu un pays populaire pour des Américains pour marcher comme EFL des professeurs ces dernières années à cause de la paie et de l'expérience culturelle (Hastings, 2012). En raison de la large distance sociale entre le KSA et les USA, les professeurs ont dû s'adapter à l'espérance et devenir des participants légitimes (Lave et Wenger, 1991) dans les communautés locales. Cette étude de cas qualitative inclut l'analyse du discours de tour(tournant)-par-tour des données d'entretien(interview) rassemblées de MA instruit d'États-Unis TESOL le diplômé, Amy, (ayant grandi aux USA) par la lentille du carnavalesque de Bakhtin (1984). L'étude a aussi inclus l'interview avec Hidy, qui a grandi dans le KSA, comme une référence pour comparer et contraster les données rassemblées d'Amy. Les découvertes révèlent que le professeur instruit d'États-Unis, Amy, le rire utilisé comme un outil rhétorique dans l'interview pour contester l'espérance culturelle de son rôle de genre dans le KSA. Les découvertes suggèrent que des règles culturelles et des tabous soient construits in situ par l'expérience individuelle.

Mots Clés: Bakhtin, carnavalesque, rhétorique, droits de genre, féminisme, enseignement de professeur, expatrié

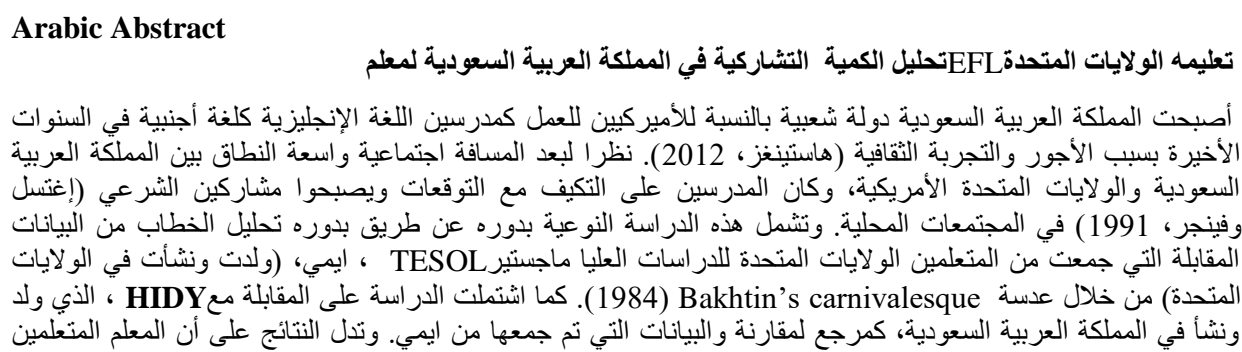




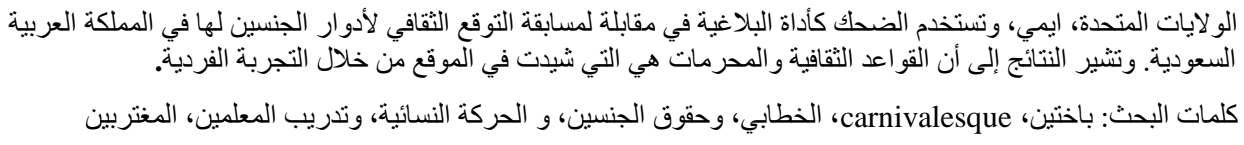

\section{German Abstract}

Die Analyse der Participatory Repertoire eines US-Gebildete EFS Lehrer in Saudi-Arabien

Die KSA hat sich zu einem beliebten Land für die Amerikaner als EFL Lehrer in den letzten Jahren zu arbeiten, weil der Lohn und kulturelle Erfahrung (Hastings, 2012). Aufgrund der großen sozialen Abstand zwischen der KSA und den USA hatten die Lehrer die Erwartung und werden legitime Beteiligung (Lave und Wenger, 1991) in den örtlichen Gemeinden anzupassen Diese qualitative Fallstudie umfasst Turn-by-Turn-Diskurs Analyse der Interviewdaten von a-USgebildeten MA TESOL Absolvent gesammelt, Amy, (geboren und in den USA angehoben) durch die Linse der Bachtins carnivalesque (1984). Die Studie umfasste auch das Interview mit Hidy, der in der KSA geboren und aufgewachsen, als Referenz zu vergleichen und die Daten von Amy gesammelt Kontrast. Die Ergebnisse zeigen, dass die US-ausgebildete Lehrer, Amy, Lachen als rhetorisches Werkzeug in dem Interview, die in der KSA die kulturelle Erwartung ihrer Geschlechterrolle zu bestreiten. Die Ergebnisse deuten darauf hin, dass die kulturellen Regeln und Tabus in situ durch individuelle Erfahrung aufgebaut sind.

Schlüsselwörter: bakhtin, carnivalesque, rhetorische, geschlecht rechte, feminismus, lehrerbildung, expatriate

\section{Malaysian Abstract \\ Menganalisis penyertaan himpunan daripada AS Guru EFL AS yang mendapat pendidikan di Arab Saudi}

KSA telah menjadi sebuah negara popular untuk rakyat Amerika untuk bekerja sebagai guru EFL pada tahun-tahun kebelakangan ini kerana gaji dan pengalaman budaya (Hastings, 2012). Oleh kerana jarak sosial yang luas antara KSA dan Amerika Syarikat, guru-guru terpaksa menyesuaikan diri dengan jangkaan dan menjadi peserta yang sah (Lave dan Wenger, 1991) dalam masyarakat setempat. Kajian kes kualitatif termasuk turn-by-turn dicourse analisis data temu bual yang dikumpul dari guru AS berpendidikan lulusan MA TESOL, Amy, (lahir dan dibesarkan di Amerika Syarikat) melalui kanta Bakhtin's carnivalesque (1984). Kajian ini juga termasuk temu bual dengan Hidy, yang dilahirkan dan dibesarkan di KSA, sebagai rujukan untuk membandingkan dan membezakan data yang dikumpul daripada Amy. Dapatan kajian menunjukkan bahawa guru AS berpendidikan, Amy, yang digunakan sebagai alat retorik dalam temu bual itu untuk bertanding jangkaan budaya dan peranan jantina dalam KSA. Hasil kajian menunjukkan bahawa kaedah-kaedah budaya dan pantang larang yang dibina di situ melalui pengalaman individu.

Kata Kunci: bakhtin, carnivalesque, retorik, hak jantina, feminin, pendidikan guru, ekspatriat 